\title{
TRANSFORMING COGNITIVE AND EMOTIONAL DISSONANCE FOR PHYSIOTHERAPY STUDENTS LEARNING MEDICAL ANTHROPOLOGY
}

\begin{abstract}
Since the 1980s physiotherapy has shifted concerns towards cultural, economic, philosophical, political and social questions, and more flexible ways of speaking about and practicing physiotherapy. In response to both global shifts and local demands, the Physiotherapy Division at the University of Cape Town (UCT) approached their Social Anthropology colleagues to teach a broader range of perspectives to their physiotherapy students. The objective of this research was to explore the changes experienced by UCT physiotherapy students exposed to a cross-disciplinary teaching environment, and discuss the possible role of the course in affecting their experience. A qualitative research design drew data from multiple sources and was analysed using an interpretive content analysis method. Using an anthropological model of transformation, the changes experienced by students were categorised into three sub-categories of 'separation', 'transition' and 'incorporation'. Emotional and cognitive changes were attributable to the course material. By attending to their emotional discomfort, physiotherapy students not only successfully incorporated anthropological concepts to healthcare but also improved their professional identities and personal self-worth.
\end{abstract}

KEY WORDS: PHYSIOTHERAPY EDUCATION, CROSS DISCIPLINARY TEACHING, MEDICAL ANTHROPOLOGY, EMOTIONAL DISCOMFORT, COGNITIVE DISSONANCE.

\section{INTRODUCTION}

In 2005, Nicholls and Larmer warned their professional colleagues in New Zealand that physiotherapy 'may not retain [its] status if it fails to address the challenges of health care reform of the future' (p.59). They, with other scholars, were suggesting a shift from the long privileged biomedical discourse of understanding health and illness toward concerns with cultural, economic, philosophical, political and social questions, and more flexible

\section{Correspondence Author:}

Helen Macdonald

School of African and Gender Studies,

Anthropology and Linguistics,

University of Cape Town

Private Bag X3 Rondebosch

Cape Town 7700

Email: helen.macdonald@uct.ac.za ways of speaking about and practicing physiotherapy (Jorgensen 2000, Nicholls and Gibson 2010, Norris and Pascale 2008, Thornquist 2006, Trede et al 2003). There has been a move from care performed through technical rationalism (under direct referral from medical practitioners, see for example Schön, 1983) to research and evidence-based practitioners working independently of medical referral. Within physiotherapy education, educators responded by introducing bio-psycho-social approaches incorporating the social determinants of health into physiotherapy curricula (Engel 1980).

In response to these demands, the Physiotherapy Division at the University of Cape Town (UCT) approached their Social Anthropology colleagues to teach a tailored module to physiotherapy students. In first year at UCT, physiotherapy students are introduced to a course Becoming a Professional; and in their second year, a course focusing on disability and healthcare. Both courses draw on a biopsycho-social model which is heavily utilised in the UCT Health Sciences (Duncan et al. 2006, Engel 1980). The Physiotherapy Division recognised that social anthropology - the branch of anthropology that deals with human culture and society - had the expertise to deliver a broad range of perspectives.

In cross-disciplinary teaching, issues typically germane to one discipline are examined through the lens of another discipline; for example, anthropological perspectives on either the body (Jorgensen 2000, Nicholls and Gibson 2010) or clinical interactions (Thornquist 1997, 2006). Anthropology investigates cultural variation among humans, collecting data about the impact of global economic and political processes 
on local cultural realities. Medical anthropology, more specifically, focuses on the structural inequality of health and human suffering, and the steps people take to explain and relieve suffering. Medical anthropology is well positioned to offer something distinctive yet complementary to the Health Sciences.

In 2011, 46 physiotherapy students were introduced to an eleven-week medical anthropology module as part of their third year course Becoming a Health Professional. The course initially met with academic staff ambivalence and student doubt as to its 'relevancy'. However, by the end of the course two things happened. Firstly, students received high examination marks after successfully integrating the course material and secondly, the formal course evaluation indicated a neutral position for continuing the course in physiotherapy curricula. When asked whether the course should be dropped from their physiotherapy programme $33 \%$ of the 2011 class answered 'Yes', the majority $46 \%$ were 'Neutral' and $21 \%$ answered 'No' ( $\mathrm{N}=24$, see table 1). Further anecdotal evidence (emails and informal conversations) indicated that some students experienced positive changes. However, physiotherapy student experience of social science curricula has yet to be systematically analysed. This qualitative study therefore sought to explore the changes experienced by UCT physiotherapy students exposed to a cross-disciplinary teaching environment, and discuss the possible role of the course in affecting their identities and self-worth. Drawing from the data this paper seeks to answer: How do physiotherapy students respond to medical anthropology and what are its transformative implications (if any)?

\section{METHOD}

Informed consent to use the cross-disciplinary teaching experience as data was gained from both 2011 and 2012 student cohorts. ${ }^{2}$ The 2012 class were asked to write a one to two page response to the following brief, resulting in 24 submissions:

1. What are the challenges that anthropology's critical and deconstructing practices may pose to your selfidentification and self-worth?

2. What is the impact on students and on their discipline?

3. How should teachers of anthropology design and teach such courses?

Research trustworthiness was enhanced through drawing qualitative data from multiple sources to provide a richer, nuanced and more credible data set to support the journal submissions. These included an independent research project conducted by eight third year anthropology student interacting with the 2011 physiotherapy class, course assignments $(\mathrm{N}=46$ for 2011 and $\mathrm{N}=41$ for 2012) and course evaluations ( $\mathrm{N}=24$ for 2011 and $\mathrm{N}=41$ for 2012), unsolicited student emails, and fieldnotes of personal interactions and general classroom observations. $^{3}$

NVivo 9 (qualitative data analysis software) was used to code data. Initially the changes experienced by the students were analysed through broad themes of emotional discomfort, disciplinary tensions and their effects on self-identity and self-worth using an interpretive method of coding. Based on the findings, a model of transformation was developed and the data re-coded in greater depth to form the basis of the analysis and discussion presented here. Data were categorised into three sub- categories of transformation: 'Separation', 'Transition' and 'Incorporation'.

\section{DESCRIPTION OF THE ANTHRO- POLOGY MODULE}

Anthropology is a discipline that encourages critical thought, questions what may be taken for granted, and examines the empirical evidence provided by everyday lived experiences. My broad goal was for students to willingly 'inhabit a more ambiguous and flexible sense of self' - a pedagogical approach favoured in my teaching that is based on recognising discomfort as a learning opportunity (Boler 1999, p.170 cited in Macdonald 2013). Briefly, the curriculum centred on the following topics. ${ }^{4}$ The course started with physiotherapy's historical beginnings in order to demonstrate shifts in physiotherapy practice and society's demands of physiotherapy (Nicholls and Cheek 2006, Kjølsrød and Thornquist 2000). The course then shifted to understanding biomedicine as a culturally defined 'conceptual model' which in turn determines which phenomena are to be looked for, how they are to be measured and verified. We examined biomedicine's dominant role in society and what this means for physiotherapy's position as the longest serving and largest allied healing profession alongside concerns for the profession's social standing and ability to compete with other professions (biokinetics) with doctoral qualifications (chiropractic). We examined lay models of aetiology, and how this leads to diverse health seeking behaviour by patients accessing different health care systems. This then allowed students to explore the process of 'medicalisation' whereby problems and experiences that

1 Physiotherapy staff projected their ambivalence by 'protecting their students'. For example, several students passed the course without submitting their (non-compulsory) essay. Also, staff perceived essay type questions as 'too difficult' for students to answer and granted extra time for the final examination.

2 UCT works with a principle of devolution to the five faculties regarding ethical clearance procedures for research with human subjects. Therefore this research was subject to the guidelines set down by Anthropology Southern Africa (ASnA 2005). The research entailed no medical intervention; the risk to research participants was low.

3 Fieldnotes refer to various notes recorded by scientists during or after their observation of a specific phenomenon they are studying. They are particularly valued in descriptive sciences such as anthropology.

4 Please contact the author for a copy of the course curriculum. 
Table 1: Course Evaluations for 2011 and 2012

\begin{tabular}{|c|c|c|c|c|}
\hline \multicolumn{5}{|c|}{$\begin{array}{l}\text { Course Evaluations for } 2011(n=24) \text { and } 2012(n=41) \\
\text { (expressed in percentages) }\end{array}$} \\
\hline Question & Year & $\begin{array}{l}\text { Strongly } \\
\text { Agree/ } \\
\text { Agree }\end{array}$ & Neutral & $\begin{array}{c}\text { Disagree / } \\
\text { Strongly } \\
\text { disagree } \\
\end{array}$ \\
\hline \multirow{2}{*}{$\begin{array}{l}\text { The course has contributed to my own } \\
\text { development/expanded my worldview/ } \\
\text { changed my thinking }\end{array}$} & 2011 & 39 & 35 & 26 \\
\hline & 2012 & 78 & 15 & 8 \\
\hline \multirow{2}{*}{$\begin{array}{l}\text { The course is relevant to my } \\
\text { programme as a whole }\end{array}$} & 2011 & 29 & 38 & 34 \\
\hline & 2012 & 49 & 41 & 10 \\
\hline \multirow{2}{*}{$\begin{array}{l}\text { The course will benefit me in my } \\
\text { physiotherapy career }\end{array}$} & 2011 & 29 & 38 & 34 \\
\hline & 2012 & 51 & 29 & 19 \\
\hline \multirow{2}{*}{$\begin{array}{l}\text { The course should be dropped from } \\
\text { the physiotherapy programme }\end{array}$} & 2011 & 33 & 46 & 21 \\
\hline & 2012 & 22 & 27 & 51 \\
\hline
\end{tabular}

have previously been explained in religious, moral, or social terms become defined as the subject of scientific medical knowledge.

The practical assignment involved each student undertaking a bodily activity with which they were unfamiliar in order to experience and theorise ideas of 'knowledge acquisition', 'bodily knowledge' or 'embodied knowledge' (Scheper-Hughes and Lock 1987). Known in anthropology as 'embodiment', it refers to knowledge carried in the body that we as humans are largely unaware. This recentering of the body, albeit from a different perspective, was aimed at complementing the bio-psychosocial model - an approach advocated by some physiotherapists (Jorgensen 2000, Nicholls et al 2009, Nicholls and Gibson 2010, Thornquist 2006).

\section{FINDINGS AND DISCUSSION}

Evidence suggests that students underwent a transformation in a way similar to that of initiates undergoing 'Rites of Passage', an anthropological model of ritual transformation first developed by Arnold van Gennep (1960) and later advanced by Victor Turner (1987). The findings are summarised using van Gennep's (1960) threefold structure involving stages of 'Separation', 'Transition' and 'Incorporation' (see table 2). During separation the individual is taken out of their familiar context, in this case physiotherapy students were exposed to anthropological ideas. During transition, the individual is exposed to ritual actions meant to effect the intended transformation. Finally, the individual is reincorporated; their new status formally established; the goal here, a more broadly based physiotherapy identity. In Victor Turner's (1987) theory of liminality - the transitional state between two phases - participants 'stand at the threshold' between their previous way of structuring their identity, time, or community, and a new way, which the ritual establishes. Turner argues that the identity of those within transition is neither that of the old nor that of the new: "their condition is one of ambiguity and paradox, a confusion of all the customary identities' (1987, p.4).

\section{Separation}

Students reacted to the course material as an epistemological collision or clash of world views (see table 2) that separated them from the comfort of their physiotherapy knowledge and identity. As one student summed up:
Anthropology challenges, in a nutshell, everything we do, think and say. It seems that in the eye of the anthropologist nothing can be accepted as "normal" or "correct", but should be critically analysed to assess its true worth (if any).

The anthropology course conceptually separated students from doing physiotherapy and asked them to learn about physiotherapy from the position of critical observer. One student commented 'I wouldn't say anthropology has thrown us into the deep end but rather into a different pool all together'. Another student after pointing out the disciplinary divide, asked: 'how do these disciplines collide and manage to exist in harmony with each other?'

I provide a detailed example from the very first class. Many students battled with the idea that their profession developed out of the massage/prostitution scandals of 1893 (Nicholls and Cheek 2006) and struggled to recognise the relevance of a historical analysis of their profession. The first reading (Nicholls and Cheek 2006) received mixed responses, with many students fixated on physiotherapy being equated to massage and prostitution. The conceptual leap from understanding that 
Table 2: Three Categories for Student Transformation

\begin{tabular}{|c|c|c|c|}
\hline Theme & Category & Codes & Sample of Quotes \\
\hline \multirow{3}{*}{$\begin{array}{c}\text { Student } \\
\text { Transformation }\end{array}$} & Separation & $\begin{array}{l}\text { Clash of } \\
\text { worldviews } \\
\text { Emotional } \\
\text { discomfort } \\
\text { Separation } \\
\text { from } \\
\text { physiotherapy } \\
\text { training }\end{array}$ & $\begin{array}{l}\text { 'I feel like nothing I do is right. Every time I read something it } \\
\text { feels like an attack.' } \\
\text { 'It is generally accepted... that "science" is the "ultimate truth"... } \\
\text { yet, for the first time in my life, this idea has been challenged.' } \\
\text { '... anthropology has challenged me to re-evaluate my beliefs... } \\
\text { it certainly took me out of my comfort zone of assumed truths.' } \\
\text { '...you are constantly at war with yourself and your self-worth } \\
\text { scrutinised.' } \\
\text { 'In anthropology, nothing is taken for granted and everything is } \\
\text { open to scrutiny.' } \\
\text { '[Anthropology] could break a lot of people down and make them } \\
\text { disheartened about what they are studying.' }\end{array}$ \\
\hline & Transition & $\begin{array}{c}\text { Normalising } \\
\text { discomforting } \\
\text { effects }\end{array}$ & $\begin{array}{l}\text { 'I think we are all feeling the relevance of the course that was } \\
\text { such a heightened topic of discussion at the beginning.' } \\
\text { 'It allows the therapist to explore more problematic areas that } \\
\text { may not have held relevance before.' } \\
\text { 'Through this anthropology course...I have come to understand } \\
\text { how the mind and body are so closely interrelated.' } \\
\text { '[The course] is really amazing as we went into details which } \\
\text { enabled us to be able to think in a broad way rather than being } \\
\text { enclosed in our comfort zone.' }\end{array}$ \\
\hline & Incorporation & $\begin{array}{l}\text { Improved self- } \\
\text { worth } \\
\text { Improved self- } \\
\text { identity } \\
\text { Feeling } \\
\text { comfortable } \\
\text { Course } \\
\text { relevance } \\
\text { Holism }\end{array}$ & $\begin{array}{l}\text { 'This level of thinking (deviant from the normal physiotherapy } \\
\text { thinking) is excellent for our growth as health care providers' } \\
\text { 'Once one gains understanding [of anthropology] then one can } \\
\text { begin to view it as a part of life, a part of who we are and our } \\
\text { daily lives.' } \\
\text { 'It will help us to become more rounded and open minded } \\
\text { thinkers and physiotherapists.' } \\
\text { 'It has given me a greater understanding about the importance } \\
\text { of treating the patient holistically.' } \\
\text { '[Anthropology] questions these values to make me realise how } \\
\text { worthy or valuable they are...' } \\
\text { 'This will make "reflecting students" who will always look for } \\
\text { ways in which to improve and better themselves.' } \\
\text { 'Personally, I feel that this course helps us to look at the world, } \\
\text { or more specifically, our physiotherapeutic views of the world, } \\
\text { in a more open-minded fashion.' }\end{array}$ \\
\hline
\end{tabular}

historical changes in physiotherapy are both a consequence of general processes in society and a calculated move on the part of individuals/organisations, to understanding the connotations of this for the way in which physiotherapists interpret the political, social, economic, governmental and practical setting in which they function as a profession today and in the future, was sometimes extremely difficult.

This conceptual separation between learning to do (an old identity) and learning about (a new identity) physiotherapy was experienced by students largely as 'an attack' on physiotherapy by anthropology. They felt their training and physiotherapy knowledge was being 'broken down', 'criticised' and 'discarded'. The 'attack' on their discipline left students feeling personally 'lost', 'confused', 'doubtful', 'fearful' and 'targeted'. Further these feelings were seen as potentially 'dangerous' or 'threatening' to their physiotherapy training - that students might potentially 'lose their faith' in physiotherapy and 
give up their physiotherapy degrees. As one student remarked:

I find it confusing that we take theories as truth until one day they are proved wrong and our basis of understanding collapses. Anthropology is quick to question our institutions. It is hard to maintain self-identification when one loses the faith in our chosen field, as our career contributes to defining us.

Yet significantly, individual students were not necessarily referring to themselves per se, rather how they imagined other classmates to be responding. For example, one student projected that 'This "breaking down" of physiotherapy is very intimidating and could be dangerous to those students who are on the edge about whether to continue the degree or not.' This consistent projection of emotional and cognitive dissonance as dangerous but only for other students (and not oneself) might explain how individually each student was able to normalise their discomfort.

\section{Transition}

In cross-disciplinary teaching, we arrive in another's classroom as the outsider. We try to lessen these classroom differences through different teaching strategies in order to affect a shared learning transition (Djohari 2011). For example, complaints that there were 'too many readings that were too long' were limited to two per week and shorter readings by physiotherapists were selected. ${ }^{5}$ Readings were apportioned across the class to lessen workloads in response to having 'no time'. Calls for 'overheads' met with an explanation that debate and conversations were necessary in order to understand the material and students were supplied with a full set of lecture notes. The course was slowed down and the teaching became more example driven when students indicated it was 'too hard and too different'. The overwhelming complaint that 'we don't know how to do essays' led to the scrapping of a second assignment in favour of concentrating on one assignment in order to master writing skills. $^{6}$

More significantly, for the 2012 class the 'pedagogy of discomfort' as a way of teaching was made explicit to students (Boler and Zembylas 2003). Boler and Zembylas (2003) foreground attending to emotional habits as a site of learning by arguing that emotions play a significant role in how and what 'we choose to see' or not see. Students (and educators) are encouraged to move outside of their comfort zones-'the inscribed cultural and emotional terrains that we occupy less by choice and more by virtue of hegemony'-by responding to emotional reactions as a cue (Boler and Zembylas 2003, p.111). By normalising their discomforting reactions, students were empowered to shift sensitivity to, and increase their comfort with, differing ways of knowing the body beyond their physiotherapy training. Students' written responses suggest this facilitated a smoother transition:

As the weeks progressed, I began to see this method of thinking as a tool that could be used in conjunction with the medical model thought process.

Our view on people, patients and the form of treatment to administer is slowly but surely changing due to gaining insight of different cultural beliefs.

Students simply grappled with the new terms and concepts introduced by anthropology, such as embodiment and body politic. But, once again, some of them expressed their appreciation for such concepts once they started to become more familiar with their meaning.

These qualitative responses suggesting 'transition' or a normalising of the discomfort brought about by the 'separation' stage are supported by quantitative data. The large portion of neutral (ambivalent) students sustained across a number of measurements in 2011 shifted to being largely supportive in the 2012 class (see table 1). Most notably, half of the 2012 class felt the course should not be dropped, which given their emotional discomfort is a finding that supports the final stage of transformation: Incorporation.

\section{INCORPORATION}

The majority of students responded that by the end of the course, despite all sorts of emotional upheavals their personal self-worth and professional self-identification had 'increased', 'improved', 'remained unchanged', and 'benefitted'. Far from integration into a cohesive group of what Turner (1987) calls 'initiands', physiotherapy students developed a 'relational identity' that can account for subjective feelings of being isolated and out-of-place. Turner accepted that initiation rituals may conserve the status quo. It is fair to say not all students integrated the material in useful ways. Nearly a quarter $(22 \%)$ of the 2012 class felt the course should be dropped from their curricula. One student provided an honest account:

I find it hard to relate/integrate what I learn in anthropology with my other physiotherapy course work. I suspect that I might have created a mental block, perhaps I have a negative attitude towards the course or something, or perhaps I'm not convinced of the authenticity of the course. I don't know.

However Turner equally felt initiation rituals held to potential to generate new thought and new custom-'a realm of pure possibility whence novel configurations of ideas and relations may arise' (Turner 1987, p.7). The majority (51\%) framed the course as 'a positive learning experience' that will benefit their physiotherapy career (see table 1) and saw themselves as 'better healers' able to treat patients 'more holistically' (see table 2). Several responses are recorded below: 
...we can identify weaknesses and/ or strengths in our current system and make changes accordingly. The ultimate goal is, after all, healing for the promotion of well-being.

Personally I feel that the main aim of this course should be to teach us to critically evaluate whatever we are doing so that we can make adaptations as need be ultimately to promote wellbeing of individuals in the current society as best we can.

I therefore believe that greater awareness of embodiment is definitely required if the future practice of physiotherapy is to uphold its status in providing holistic patient care.

Where students were able to master the epistemological and emotional challenges wrought by anthropology and the anthropologist, they resorted to a celebration of their distinctiveness as physiotherapists.

\section{CONCLUSION}

As an occupation, physiotherapy attracts students with more applied concerns, who are more attracted to learning how to do physiotherapy and less attracted to learning about physiotherapy-a finding similar to that of Djohari's (2011) study of Development Studies students learning anthropology. Learning about physiotherapy from a critical social science perspective was both cognitively and emotionally demanding of physiotherapy students. Personal discomforts and transformations are considered normal within anthropology's critical practices and are received as such by students who register for anthropology courses (Macdonald 2013). For physiotherapy students, who are neither suspecting of nor prepared for this critique of their chosen profession, the cognitive and emotional effects are often unwelcome initially and can leave some feeling like 'strangers in their own homes, unable to integrate themselves into former ways of life' (Coleman and Simpson 2004, p.30, cited in Djohari, 2011, p.22).
However, the majority of physiotherapy students were able to reintegrate themselves both personally and professionally. This paper seeks to contribute to physiotherapy education by recommending that explicit attention be given to the emotional labour students undertake when cross-disciplinary teaching is introduced into their curricula. Physiotherapy students learning medical anthropology are likely to experience personal discomfort and/or feel inconsistency with their established professional identity and possibly other identities. At the same time, if managed through a model of ritual transition and pedagogy of discomfort, the majority of students can and will incorporate critical analysis and alternative ways of knowing the body into their personal and professional development. By making the act of emotional labouring explicit, students are better enabled to incorporate complementary yet different disciplinary perspectives into their physiotherapy curriculum while enhancing their selfidentity and self-worth.

\section{REFERENCES}

Anthropology Southern Africa (ASnA) 2005 Ethical Guidelines and Principles of Conduct for Anthropologists. Anthropology Southern Africa 28(3\&4):142-3

Boler M and Zembylas M 2003 Discomforting truths: The emotional terrain of understanding difference. In: Trifonas P (ed) Pedagogies of Difference: Rethinking Education for Social Change, pp110-135. Routledge, New York

Djohari N 2011 'Breaking other people's toys': Reflections on teaching critical anthropology in development studies. Teaching Anthropology 1(1):21-29

Duncan M, Alperstein M, Mayers P, Olckers L and T Gibbs 2006 Not just another multi-professional course! Part 1. Rationale for a transformative curriculum. Medical Teacher 28(1):59-63

Engel G 1980 The clinical application of the biopsychosocial model. The American Journal of Psychiatry 137(5):535-44

Jorgensen P 2000 Concepts of body and health in physiotherapy: The meaning of the social/cultural aspects of life. Physiotherapy Theory and Practice 16:105-115
Kjølsrød L and Thornquist E 2000 From a liberal occupation to an occupation of the welfare state: Norwegian physiotherapy 1960-2000. Acta Sociologica 47(3):277-289

Macdonald H 2013 Inviting discomfort: Foregrounding emotional labour in teaching anthropology in post-apartheid South Africa. Teaching in Higher Education. Online http://dx.doi.org/10.108 0/13562517.2013.795938

Nicholls DA and Cheek J 2006 Physiotherapy and the shadow of prostitution: The Society of Trained Masseuses and the massage scandals of 1894. Social Science \& Medicine 62:2336-48

Nicholls DA and Gibson BE 2010 The body and physiotherapy. Physiotherapy Theory and Practice 26(8):497-509

Nicholls DA and Larmer P 2005 Possible futures of physiotherapy: An exploration of the New Zealand context. New Zealand Journal of Physiotherapy 33(2):55-60

Nicholls DA, Reid DA and Larmer PJ 2009 Crisis, what crisis? Revisiting 'possible futures for physiotherapy'. New Zealand Journal of Physiotherapy $37(3): 105-114$

Norris M and Pascale A 2008 Culture and physiotherapy. Diversity in Health and Social Care 5:151-9

Scheper-Hughes N and Lock M 1987 The mindful body: A prolegomenon to future work in medical anthropology. Medical Anthropology Quarterly $1: 6-41$

Schön DA 1983 The Reflective Practitioner: How Professionals Think in Action. Basic Books, New York

Thornquist E 1997 Three voices in a Norwegian living room: An encounter from physiotherapy practice. Medical Anthropology Quarterly 11(3): 324-351

Thornquist E 2006 Face-to-face and hands-on: assumptions and assessments in the physiotherapy clinic. Medical Anthropology 25:65-97

Trede F, Higgs J, Jones M and Edwards I 2003 Emancipatory practice: A model for physiotherapy practice? Focus on Health Professional Education: A Multidisciplinary Journal 5(2):1-13

Turner V 1987 Betwixt and between: The liminal period in rites of passage. In: Mahdi LC, Foster S and Little M (eds) Betwixt and Between: Patterns of Masculine and Feminine Initiation, pp3-19. Open Court, La Salle Illinois

van Gennep A 1960 The Rites of Passage. University of Chicago, Chicago 